\title{
PERBAIKAN SISTEM DAN STASIUN KERJA PADA SUB-ASSEMBLY $(S A)$ DOOR PT. MERCEDES-BENZ INDONESIA
}

\author{
Nofi Erni ${ }^{1}$, Silvi Ariyanti ${ }^{2}$, dan Rama Dinara ${ }^{3}$ \\ ${ }^{1}$ Program Studi Teknik Industri, Universitas Esa Unggul \\ ${ }^{2}$ Program Studi Teknik Industri, Universitas Mercu Buana \\ ${ }^{3}$ Program Studi Teknik Industri, Universitas Tarumanagara \\ e-mail: ramadinara.widyanta@gmail.com; ariyantisilvi41@gmail.com
}

\begin{abstract}
ABSTRAK
PT. Mercedes Benz Indonesia adalah sebuah perusahaan Jerman yang berusaha untuk memenuhi kebutuhan dan keinginan konsumen kendaraan roda empat di Indonesia. Penelitian ini dilakukan di stasiun kerja SA yang berfungsi untuk merakit pintu mobil. Kegiatan merakit pintu di stasiun SA sebelum perbaikan dilakukan dengan sistem "1 Man 2 Set Of Doors". Dalam sistem kerja penelitian ini diubah menjadi "1 Man 1 Set Of Doors". Hasil yang diperoleh pada waktu siklus perakitan pintu masih terlalu lama (rata-rata 66,02 menit) dan desain stasiun kerja tidak dianggap optimal karena jarak dari operator terlalu panjang (total jarak tempuh sepanjang 907,6 m). Untuk mengurangi waktu siklus dan jarak tempuh ditingkatkan dengan mengurangi jumlah jig digunakan pada pintu. Setelah perubahan pada tata letak dan simulasi menggunakan software ProModel, hasilnya menunjukkan pengurangan waktu proses untuk pintu depan sebesar $10 \%$ dan pintu belakang dengan $13 \%$. Hal ini menyebabkan peningkatan produksi per bulan depan pintu 35 unit, dari 307 unit menjadi 342 unit dan pintu belakang sebanyak 47 unit, dari 323 unit menjadi 370 unit.
\end{abstract}

Kata Kunci: Cycle Time, Stasiun Kerja, Jarak Tempuh, Simulasi, Promodel

\begin{abstract}
PT. Mercedes Benz Indonesia is a German company that strives to meet the needs and desires of consumer's four-wheel vehicles in Indonesia. This research was conducted at the work station SA that serves to assemble the car door. Activities assemble the door at the station SA before improvements were made to the system "1 Man 2 Set of Doors". In this research work system was changed to "1 Man 1 Set of Doors". The results obtained on the cycle time door assembly is still too long (an average of 66.02 minutes) and the design of work stations are not considered optimal because of the distance from the operator is too long (the total mileage along $907.6 \mathrm{~m}$ ). To reduce cycle time and mileage improved by reducing the number of jigs used on the door. After changes to the layout and simulation using ProModel software, the results showed a reduction in the processing time for the front door by $10 \%$ and rear doors with 13\%. This results in increased production per month doorstep 35 units, from 307 units to 342 units and the rear door as much as 47 units, from 323 units to 370 units.
\end{abstract}

Keyword: Cycle Time, Work Station, Walking Distance, Simulation, Promodel

\section{PENDAHULUAN}

PT. Mercedes Benz Indonesia yang berasal dari Jerman merupakan salah satu perusahaan yang memasarkan produknya dalam memenuhi kebutuhan industri kendaraan roda empat di Indonesia. Terdapat beberapa lini perakitan di PT. Mercedes Benz Indonesia, yaitu trimming line, hangs on parts, sub-assembly (SA) line, and mechanical line. Untuk lini sub-assembly terdiri dari SA cockpit, SA seat, SA door, dan panoramic.

Penelitian ini secara khusus membahas stasiun SA door. SA door merupakan stasiun yang bekerja untuk merakit pintu mobil, pengerjaan $S A$ door dilakukan di 2 stasiun dengan jumlah 2 tenaga kerja di tiap stasiun. Cycle time dari pengerjaan $S A$ door saat ini dinilai masih terlalu panjang dan desain stasiun kerja juga dinilai belum optimal akibat jarak tempuh tiap operator yang juga dianggap masih panjang. Hal ini berdampak pada keinginan perusahaan untuk menemukan desain stasiun dan sistem kerja baru pada bagian SA door yang tentunya dengan harapan output yang lebih efisien. 
Adapun tujuan dari penelitian ini adalah memberikan usulan perbaikan sistem kerja dan desain stasiun kerja baru pada SA door PT. Mercedes Benz Indonesia serta membandingkan cycle time kondisi aktual dan usulan dengan simulasi promodel. Manfaat dari penelitian ini antara lain adalah untuk mengurangi waktu proses serta meningkatkan jumlah produksi pada stasiun SA door PT. Mercedes Benz Indonesia.

Peta proses operasi adalah diagram yang menggambarkan langkah-langkah proses pengerjaan material, mulai dari bahan baku hingga menjadi komponen atau produk jadi [1]. Peta aliran proses adalah diagram yang menunjukkan urutan-urutan dari operasi, pemeriksaan, transportasi, menunggu dan penyimpanan yang terjadi selama satu proses berlangsung. Spaghetti diagram merupakan sebuah representasi visual atau peta yang menunjukkan aliran kerja kontinu dalam suatu proses sehingga dapat diidentifikasi pengulangan dari aliran kerja [2]. Diagram ini menunjukkan tata letak dari area kerja serta pergerakan dari pekerja pada area kerja.

Sebelum melakukan pengukuran waktu siklus, waktu normal, serta waktu baku hal yang harus dilakukan terlebih dahulu adalah: uji keseragaman data

Hitung rata-rata dari data [3]:

$$
\overline{\mathrm{X}}=\sum \frac{\mathrm{Xi}}{k}
$$

Dimana :

$\mathrm{X}$ : data yang ada

$\mathrm{K}$ : jumlah data

Hitung standar deviasi dari waktu penyelesaian:

$$
\sigma=\sqrt{\frac{\sum(\mathrm{Xi}-\overline{\mathrm{X}})^{2}}{\mathrm{~N}-1}}
$$

Dimana :

Xi: data ke-i

$\overline{\mathrm{X}}$ : rata-rata

$\mathrm{N}$ : jumlah data

Tentukan batas kontrol atas dan kontrol batas bawah dengan rumus:

$$
\begin{aligned}
& B K A=\overline{\bar{x}}+Z a / 2 \times \sigma_{\bar{x}} \\
& B K B=\overline{\bar{x}}-Z a / 2 \times \sigma_{\bar{x}}
\end{aligned}
$$

Selanjutnya adalah dengan melakukan uji kecukupan data yang dapat dihitung dengan rumus di bawah ini :

$N^{\prime}=\left(\frac{k / s \sqrt{N \sum X_{i}^{2}-\left(\sum X_{i}\right)^{2}}}{\sum X_{i}}\right)^{2}$

Dimana :

N' : jumlah pengamatan yang seharusnya dilakukan.

$\mathrm{K}$ : tingkat kepercayaan dalam pengamatan. $(\mathrm{k}=1.96$, kepercayaan $=95 \%)$.

$\mathrm{S}$ : derajat ketelitian dalam pengamatan (5\%).

$\mathrm{N}$ : jumlah pengamatan yang sudah dilakukan.

$\mathrm{Xi}$ : data pengamatan

Uji kenormalan dilakukan menggunakan teknik Kolmogorov-Smirnov dengan

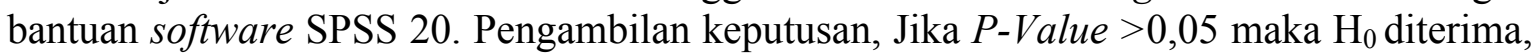
dan jika $P$-Value $<0,05$ maka $\mathrm{H}_{0}$ ditolak [.

Waktu siklus merupakan waktu aktual dari proses produksi untuk satu unit produk. Waktu siklus memberikan informasi mengenai seberapa sering operator dapat memproduksi produk dengan sumber daya yang ada. Penentuan waktu siklus untuk suatu proses, harus dilakukan melalui pengamatan, salah satu caranya dengan menggunakan jam 
henti. Waktu siklus dapat dihitung dengan rumus [3] :

$X=\frac{\Sigma x}{n}$

Dimana:

$\mathrm{X}$ : Waktu siklus

$\mathrm{x}$ : Waktu pengamatan

$\mathrm{n}$ : Jumlah pengamatan yang dilakukan

Waktu normal merupakan waktu kerja yang telah mempertimbangkan faktor penyesuaian, yaitu waktu siklus rata-rata dikalikan dengan faktor penyesuaian. Rating factor pada umumnya diaplikasikan untuk menormalkan waktu kerja yang diperoleh dari pengukuran kerja akibat tempo operator yang tidak stabil. Waktu normal dapat dihitung dengan rumus [3]:

Waktu Normal $=$ Waktu Siklus $\times$ Penyesuaian

Waktu baku merupakan waktu sebenarnya yang digunakan operator untuk memproduksi satu unit dari data jenis produk. Penentuan waktu baku memperhitungkan toleransi beristirahat operator untuk mengatasi kelelahan. Waktu baku dapat dihitung dengan rumus [3]:

Waktu Baku $=$ Waktu Normal $\times(l+1)$

Pengukuran jarak dilakukan lewat pengamatan langsung di lapangan yang dibantu dengan analisis pemetaan proses yakni peta aliran proses dan diagram spageti. Sedangkan untuk pengukuran jarak kondisi usulan ditentukan dengan bantuan software AUTOCAD 2014 dengan metode Eucladean.

Penentuan desain stasiun usulan dilakukan dengan pembuatan Activity Relationship Chart, yang merupakan aktivitas atau kegiatan antara masing-masing bagian yang menggambarkan penting tidaknya kedekatan ruangan. Kemudian dilanjutkan dengan pembuatan Activity Relationship Diagram dengan metode Relationship Diagramming, untuk mendapatkan gambaran tentang tata letak suatu departemen relative terhadap departemen lainnya [4].

ProModel (Production Modeler) adalah perangkat simulasi untuk memodelkan berbagai macam sistem manufaktur dan jasa. Terdapat pemodelan elemen pada promodel antara lain location, entities, arrival, processing, resource, dan path network. Perhitungan jumlah replikasi menggunakan rumus [5]:

Half Width $=\frac{\left(t_{n-1, \alpha / 2}\right) \times s}{\sqrt{n}}$

$\mathrm{N}^{\prime}=\left[\frac{\left(z_{\alpha / 2}\right) \times s}{e}\right]^{2}$

Number of Replication merupakan banyak replikasi atau pengulangan yang akan digunakan untuk pengeksekusian sistem simulasi. Penentuan banyaknya replikasi menggunakan metode absolute dengan error yang akan ditanggung sebesar nilai half width dan tingkat kepercayaan 95\%. Kemudian dilanjutkan dengan uji validitas hasil simulasi dengan ketentuan harga kurang dari 5\%. Validasi model merupakan langkah untuk menguji apakah model yang telah disusun dapat merepresentasikan sistem nyata [5].

\section{METODE PENELITIAN}

Langkah-langkah yang digunakan dalam penelitian ini dapat dilihat pada Gambar 1. 

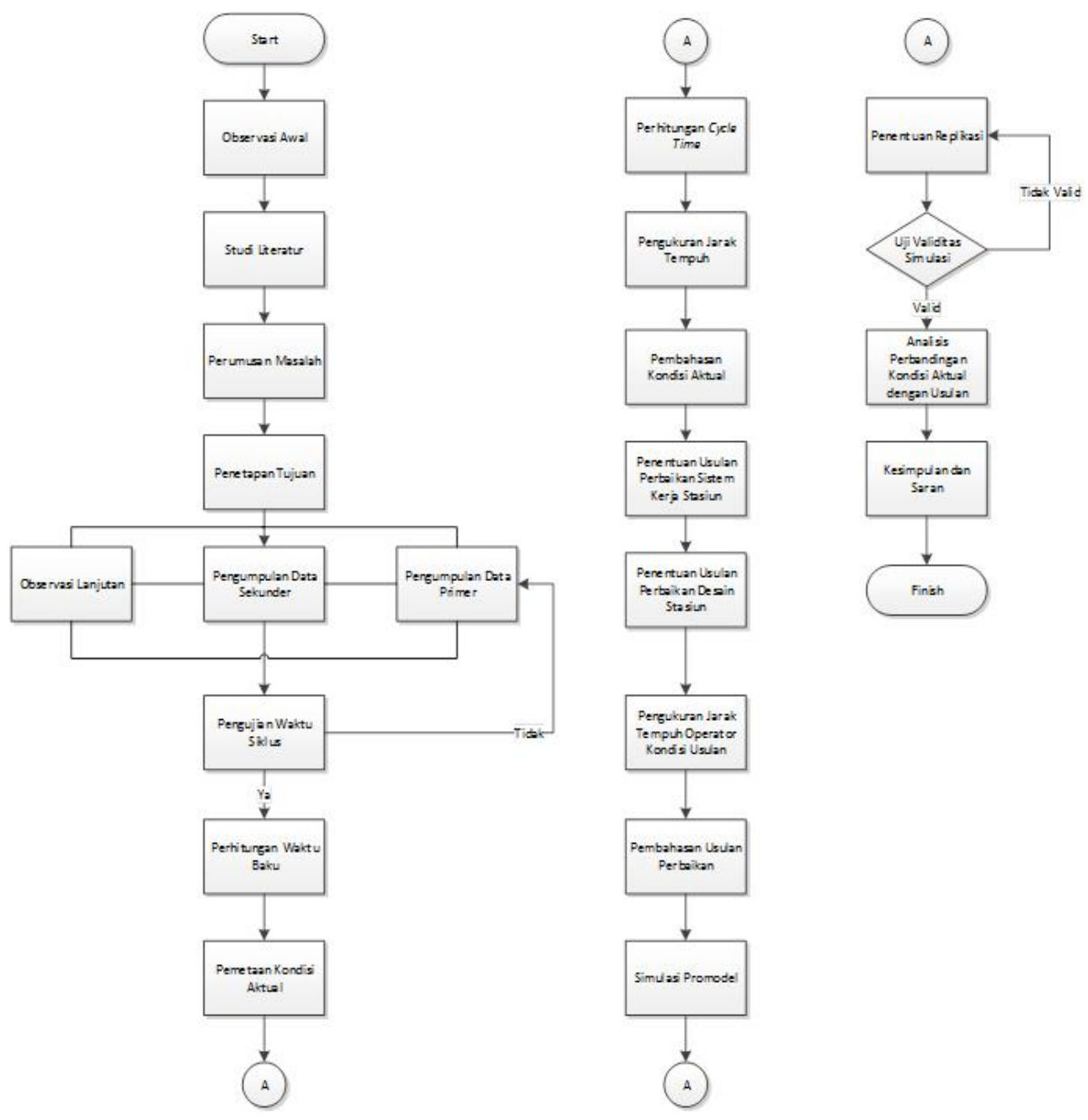

Gambar 1. Flowchart Metode Penelitian

\section{PENGUMPULAN DATA}

Pengumpulan data terbagi menjadi 2 yaitu: pengumpulan data sekunder dan pengumpulan data primer. Pengumpulan data sekunder, diperoleh dari database departemen berupa data urutan proses, desain tata letak stasiun, serta jarak tempuh operator menuju fasilitas-fasilitas stasiun. Pengumpulan data primer, berupa data yang diperoleh dari hasil pengamatan langsung. Alat bantu yang digunakan adalah video, jam henti, papan pengamatan serta meteran.

Pengumpulan data dilakukan untuk menghitung cycle time, melakukan perbaikan tata letak fasilitas stasiun, serta digunakan sebagai input dalam simulasi dengan software Promodel.

\section{Perhitungan Waktu Baku}

\section{HASIL DAN PEMBAHASAN}

Data yang diambil adalah waktu proses tiap elemen kerja dan waktu transportasi per elemen kerja. Setelah dilakukan uji keseragaman, uji kecukupan, dan uji normalitas dilakukan proses perhitungan waktu baku untuk masing-masing data dengan faktor penyesuaian (metode Westinghouse) sebesar 1,28 dan faktor kelonggaran sebesar 1,1555 $[6]$. 


\section{Analisis Proses}

Kondisi aktual untuk $S A$ door, terdapat 2 stasiun $S A$ door dengan masing-masing stasiun memiliki 2 operator dan 1 jig door (kapasitas 4 pintu). Tiap operator bertanggung jawab untuk 2 unit pintu dengan urutan pekerjaan dimulai dari pintu bagian belakang yang kemudian dilanjutkan dengan pintu bagian depan. Berdasarkan hasil pengamatan, maka dilakukan pembuatan Peta Proses Operasi guna mengetahui secara detail urutan proses diikuti dengan data waktu siklus rata-rata yang diperoleh dari 16 kali pengamatan untuk tiap proses pada 4 operator berbeda. Gambar peta proses operasi pintu bagian depan dapat dilihat pada Gambar 2.

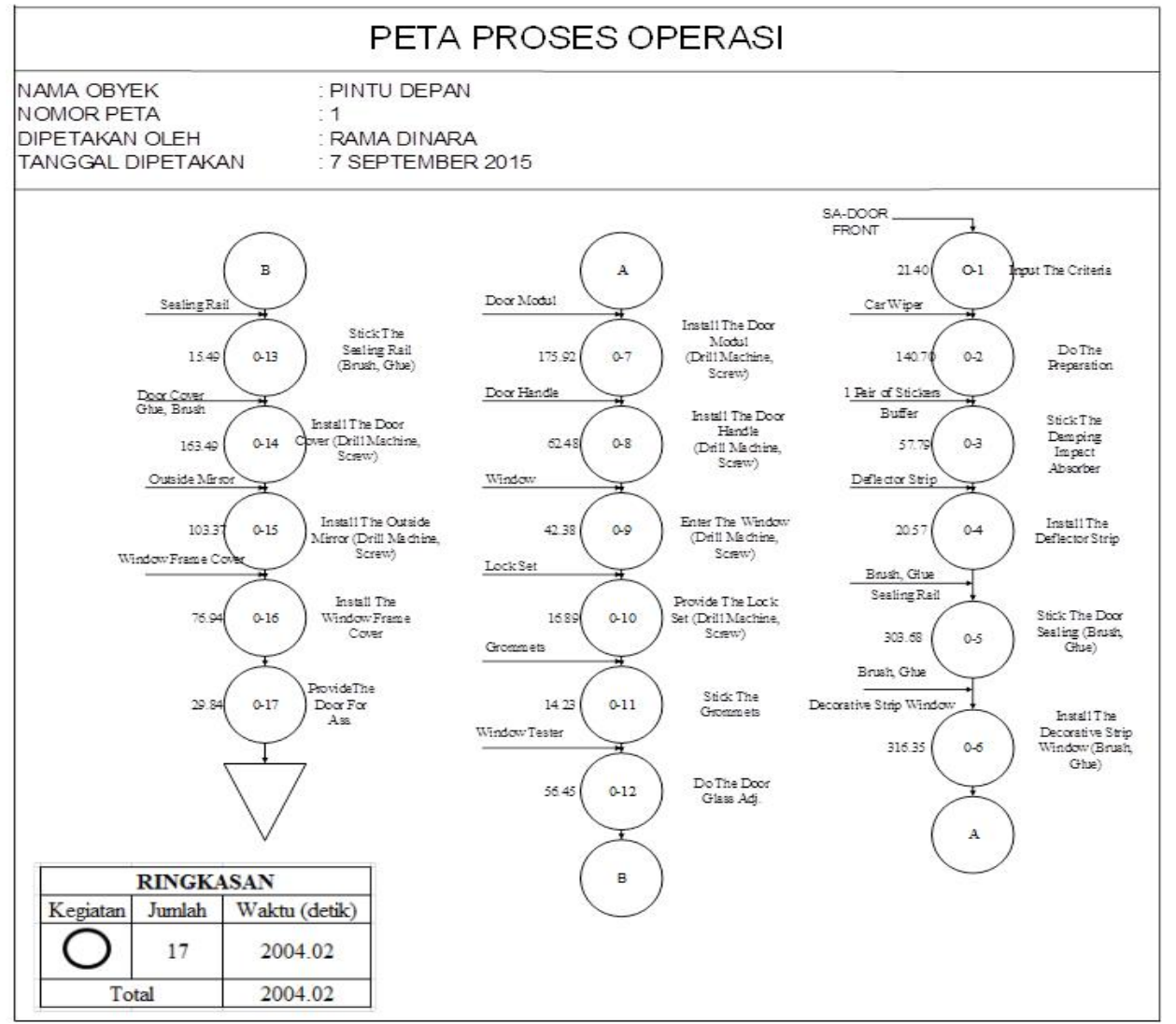

Gambar 2. Peta Proses Operasi Pintu Bagian Depan

Berikut ini merupakan keterangan dari operasi proses ke-1 hingga operasi proses ke-17. Tabel keterangan peta proses operasi pintu bagian depan dapat dilihat pada Tabel 1 .

Tabel 1. Keterangan Peta Proses Operasi Pintu Bagian Depan

\begin{tabular}{ccc}
\hline OPERASI & PROSES & KETERANGAN \\
\hline O-1 & I/O Criteria & Memasang pintu pada jig \\
O-2 & Preparation & Membersihkan pintu dengan lap pintu \\
O-3 & Damping Impact Absorber & Memasang 2 stiker balok dan 1 penyangga \\
O-4 & Deflector Strip & Memasang penangkal air di bawah pintu \\
O-5 & Door Sealing Ass. & Memasang rangka karet disekeliling pintu \\
O-6 & Decorative Strip Window & Memasang dudukan kaca \\
O-7 & Door Modul Ass. & Memasang rangka dalam pintu \\
O-8 & Door Handle Ass. & Memasang dudukan pegangan pintu \\
O-9 & Window & Memasang kaca pada pintu \\
O-10 & Provide Lock Set & Memasang tombol kunci pada pegangan pintu \\
O-11 & Grommets & Memasang penutup rongga rangka \\
\hline
\end{tabular}


Tabel 1. Keterangan Peta Proses Operasi Pintu Bagian Depan (Lanjutan)

\begin{tabular}{ccc}
\hline OPERASI & PROSES & KETERANGAN \\
\hline O-12 & Door Glass Adj. & Melakukan pengetesan kaca \\
O-13 & Sealing Rail & Memasang list depan pintu \\
O-14 & Door Covering Ass. & Memasang cover dalam pintu \\
O-15 & Outside Mirror & Memasang Spion \\
O-16 & Window Frame Cvr & Memasang cover dudukan kaca bagian dalam \\
O-17 & Provide Door for Ass. & Memindahkan pintu ke trolley logistik \\
\hline
\end{tabular}
Gambar 3.

Gambar pintu sebelum proses, work in process, setelah proses dapat dilihat pada

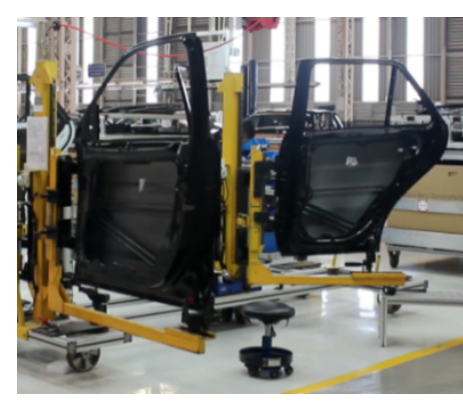

a

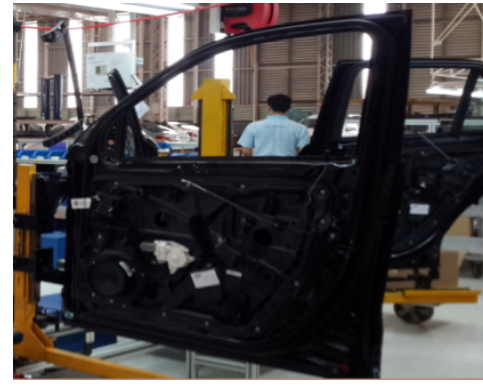

b

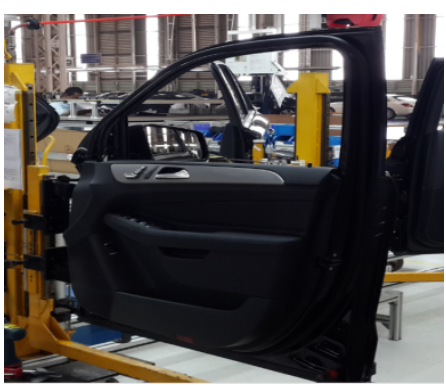

$\mathrm{C}$

Gambar 3. Pintu (a). Sebelum Proses (b). Work in Process (c). Setelah Proses

Kemudian dilanjutkan dengan pembuatan Peta Aliran Proses, untuk mengetahui informasi transportasi dan waktu menunggu. Hasil dari pemetaan ini terlihat banyak sekali transportasi yang terjadi dari jig door terhadap picking trolley. Banyaknya transportasi yang terjadi tentunya menghasilkan jarak tempuh yang semakin panjang. Gambar peta aliran proses pintu bagian depan dapat dilihat pada Gambar 4 .

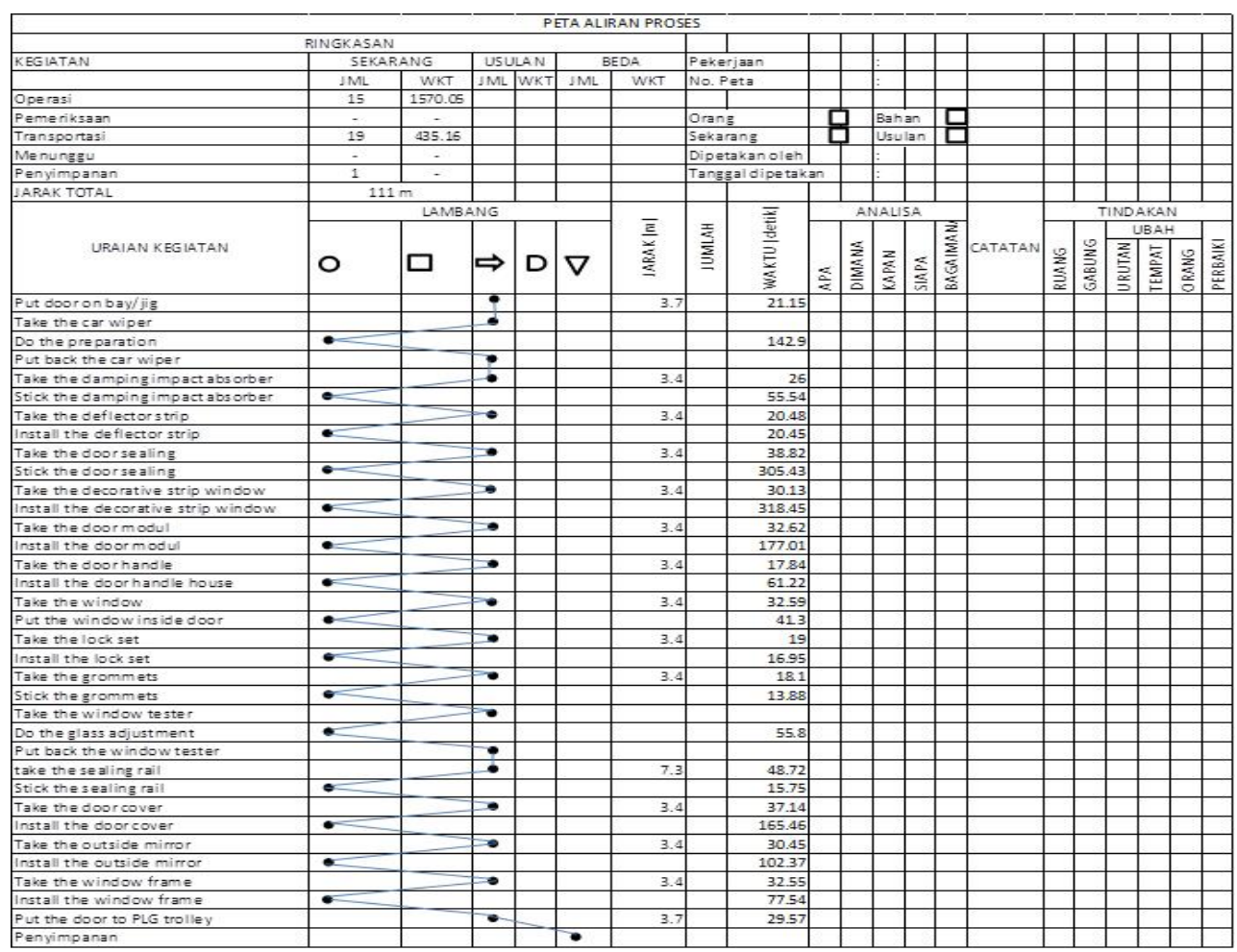

Gambar 4. Peta Aliran Proses Pintu Bagian Depan 
Langkah terakhir dalam pemetaan proses adalah pembuatan diagram spaghetti. Pemetaan dilakukan dengan menggambarkan tata letak fasilitas didalam stasiun kerja serta aliran kerja operator. Dalam pembuatannya, aliran kerja operator aktual dan tata letak stasiun kerja diperoleh dari pengamatan. Diagram ini menunjukkan aliran operator dari awal hingga akhir proses. Gambar diagram spaghetti stasiun $S A$ Door dapat dilihat pada Gambar 5.

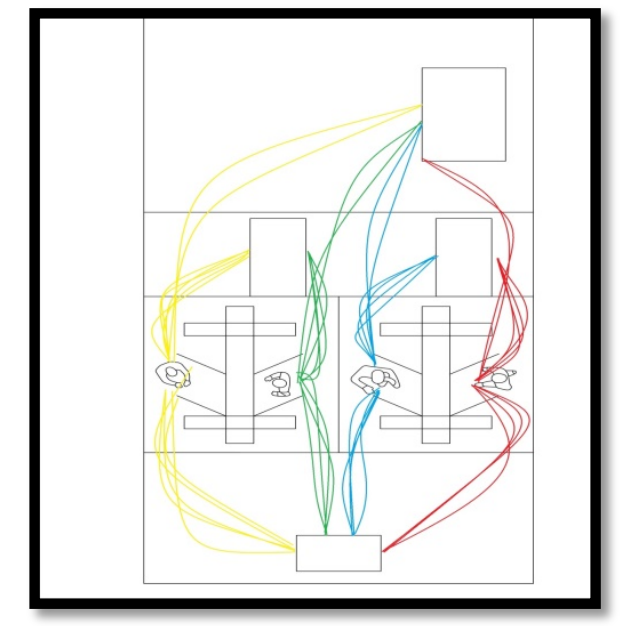

Gambar 5. Diagram Spaghetti Stasiun SA Door

\section{Perhitungan Cycle Time}

Perhitungan Cycle Time diperoleh dari jumlah tanggung jawab kerja tiap operator yakni, satu pintu bagian depan beserta transportasinya dan satu pintu bagian belakang beserta transportasinya. Cycle time rata-rata untuk ke-empat operator adalah sebesar 66,02 menit (pintu depan=33,40 menit; pintu belakang=32,62 menit).

\section{Pengukuran Jarak Tempuh}

Pengukuran jarak dilakukan dengan bantuan diagram spageti dan analisis jarak tempuh per operator berdasarkan aliran proses. Total jarak tempuh ke-empat operator adalah sebesar 907,6 m. Gambar analisis jarak tempuh per operator dapat dilihat pada Gambar 6.

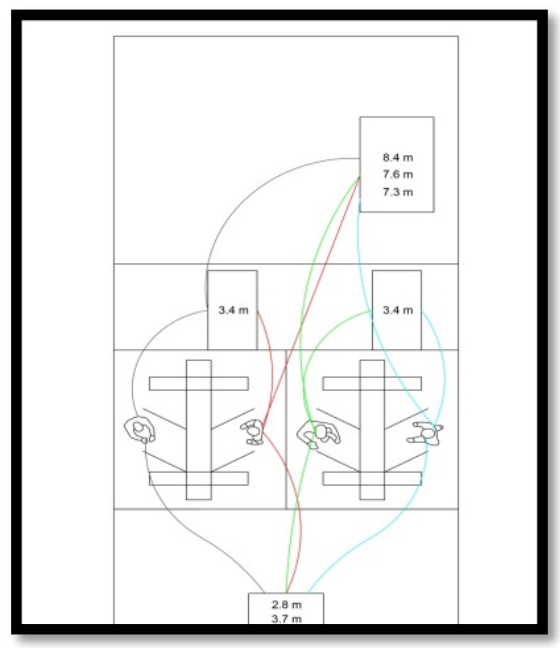

Gambar 6. Analisis Jarak Tempuh per Operator 


\section{Usulan Tata Letak}

Penentuan layout diawali dengan pembuatan Activity Relationship Chart (ARC), pembuatan $A R C$ ini untuk menentukan hubungan antar fasilitas dalam penentuan layout usulan. Gambar Activity Relationship Chart dapat dilihat pada Gambar 7.

\begin{tabular}{|c|c|}
\hline Logistic Trolley & 1 \\
\hline Jig Door & 2 \\
\hline Picking Trolley & 5 \\
\hline Picking Trolley & 4 \\
\hline Chrome Trolley & 5 \\
\hline
\end{tabular}

\begin{tabular}{|c|c|c|}
\hline No & Simbol & Keterangan \\
\hline 1 & A & Absolutely Important \\
\hline 2 & E & Espicially Important \\
\hline 3 & I & Important \\
\hline 4 & O & Ordinary \\
\hline 5 & U & Unimportant \\
\hline 6 & X & Undesirable \\
\hline
\end{tabular}

\begin{tabular}{|c|c|}
\hline 1 & $\begin{array}{c}\text { Menggunakan Tenaga Kerja yang } \\
\text { sama }\end{array}$ \\
\hline 2 & Mengurangi Waktu Delay \\
\hline 3 & Memudahkan Pemindahan \\
\hline 4 & Melaksanakan Kegiatan yang sama \\
\hline 5 & Memudahkan Koordinasi \\
\hline
\end{tabular}

Gambar 7. Activity Relationship Chart

Dilanjutkan dengan pembuatan Activity Relationship Diagram untuk menentukan desain stasiun. Pendekatan algoritmik yang digunakan adalah metode Relationship Diagramming, dimana metode ini membutuhkan input dari Activity Relationship Chart dan worksheet untuk memudahkan pemilihan departemen yang akan masuk ke dalam block plant. Metode relationship diagramming ini mengutamakan departemen yang memiliki hubungan derajat paling penting sehingga cocok digunakan sebagai dasar untuk merancang tata letak stasiun [7]. Gambar Activity Relationship Diagram dapat dilihat pada Gambar 8.

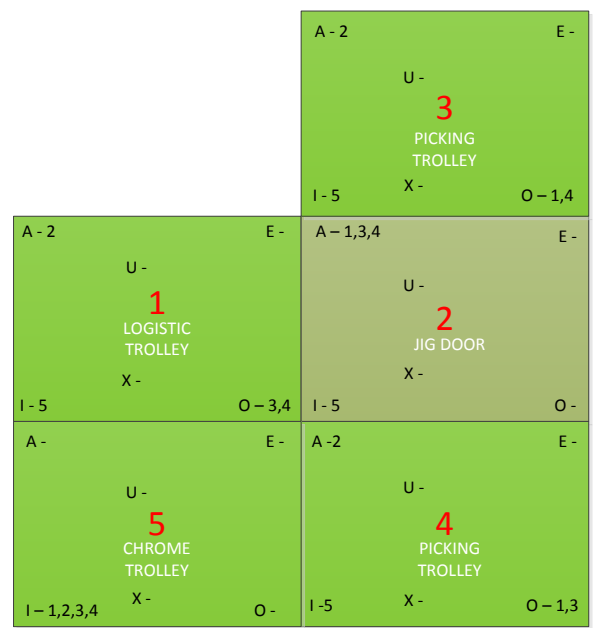

Gambar 8. Activity Relationship Diagram

Berikut ini merupakan tata letak awal dan usulan stasiun $S A$ door. Gambar tata letak awal dan usulan stasiun $S A$ door dapat dilihat pada Gambar 9 dan Gambar 10.

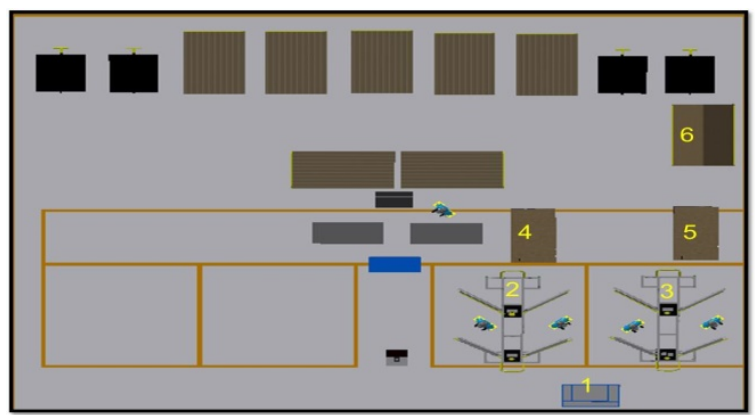

Logistic Trolley

2. Jig Door1

3. Picking Trolley 1

4. Picking Trolley2

5. Chrome Trolley

Gambar 9. Tata Letak Awal 


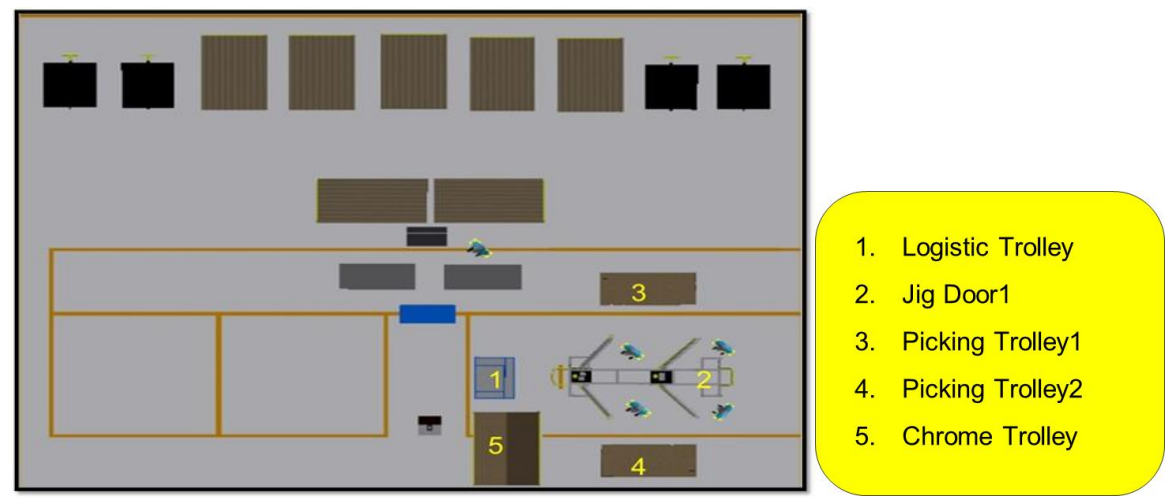

Gambar 11. Tata Letak Usulan

\section{Pengukuran Jarak Tempuh Kondisi Usulan}

Pengukuran jarak tempuh operator dari usulan perbaikan tata letak stasiun dibutuhkan untuk menjadi input dalam merancang simulasi . Pengukuran jarak dilakukan dengan bantuan software AUTOCAD 2014 dengan metode Eucladean. Setelah mengetahui jarak menuju tiap fasilitas dilakukan perhitungan total jarak dengan bantuan peta aliran proses dan diagram spageti yang sudah dibuat sebelumnya. Hasil perhitungan menunujukkan total jarak tempuh operator menjadi 573,2 m.

\section{Simulasi Dengan Promodel}

Simulasi dilakukan dengan bantuan program Promodel. Simulasi akan dilakukan untuk tata letak aktual dan tata letak usulan. Hasil simulasi nantinya akan dianalisa secara lebih lanjut sehingga diketahui tata letak mana yang lebih baik dari segi produktifitas yang tentunya dilihat dari cycle time yang tercipta. Data cycle time yang digunakan adalah data cycle time rata-rata per elemen kerja pada ke-empat operator. Uji replikasi dan validasi juga harus diperhatikan.

Tabel 2 Perbandingan Hasil Aktual dan Usulan

\begin{tabular}{cccc}
\hline \multicolumn{4}{c}{ Rekap Hasil Simuasi Cycle Time untuk 1 Pasang Pintu } \\
\hline & Aktual (menit) & Usulan (menit) & Pengurangan (\%) \\
\cline { 2 - 4 } Pintu Depan (Front Door) & 34,41 & 30,85 & 10 \\
Pintu Belakang (Rear Door) & 32,71 & 28,53 & 13 \\
\hline
\end{tabular}

Kemudian dilakukan perhitungan jumlah produksi berdasarkan kondisi aktual dan kondisi usulan sebagai berikut.

Kondisi Aktual

Peningkatan produksi per hari pintu bagian depan: $\frac{(8 \text { jam ker ja } \times 60 \text { menit })}{34,41}=13,95 \approx 14$ unit.

Produksi per bulan=13,95 x 22 hari $=306,89 \approx 307$ unit.

Peningkatan produksi per hari pintu bagian belakang: $\frac{(8 \text { jam ker ja } \times 60 \text { menit })}{32,71}=14,67 \approx 15$ unit.

Produksi per bulan=14,67 x 22 hari $=322,84 \approx 323$ unit.

Kondisi Usulan

Peningkatan produksi per hari pintu bagian depan $=\frac{(8 \text { jam ker ja } \times 60 \text { menit })}{30,85}=15,56 \approx 16$ unit.

Produksi per bulan=13,95 x 22 hari $=342,30 \approx 342$ unit.

Peningkatan produksi per hari pintu bagian belakang $=\frac{(8 \text { jam ker ja } \times 60 \text { menit })}{28,53}=16,82 \approx 17$ unit.

Produksi per bulan=14,67 x 22 hari $=370,14 \approx 370$ unit. 
Tabel 3.

Perbandingan hasil output produksi kondisi aktual dan usulan dapat dilihat pada

Tabel 3 Perbandingan Hasil Output

\begin{tabular}{lcc}
\hline \multicolumn{3}{c}{ Perbandingan Hasil Output (Produk//bulan) } \\
\hline & Aktual (unit) & Usulan (unit) \\
\cline { 2 - 3 } Pintu Depan (Front Door) & 307 & 342 \\
Pintu Belakang (Rear Door) & 323 & 370 \\
\hline
\end{tabular}

\section{KESIMPULAN}

Berdasarkan hasil penelitian pada stasiun SA door diperoleh perbaikan stasiun kerja SA Door dari sistem "1 Man 2 Set Of Door" menjadi "1 Man 1 Set Of Door" serta usulan perbaikan desain stasiun kerja dengan perubahan tata letak fasilitas yang ada. Perbaikan dilakukan dengan pengurangan jumlah jig door yang digunakan. Setelah dilakukan perubahan tata letak diperoleh hasil yang menunjukkan pengurangan waktu proses untuk pintu bagian depan sebesar 10\%, dari 34,41 menit menjadi 30,85 menit. Hal ini juga berdampak pada peningkatan jumlah produksi per bulan untuk pintu bagian depan sebanyak 35 unit, dari 307 unit menjadi 342 unit. Hasil simulasi juga menunjukkan pengurangan waktu proses untuk pintu bagian belakang sebesar 13\%, dari 32,62 menit menjadi 28,53 menit. Hal ini juga berdampak pada peningkatan jumlah produksi per bulan untuk pintu bagian belakang sebanyak 47 unit, dari 323 unit menjadi 370 unit. Selain pengurangan waktu, perubahan tata letak juga berdampak pada pengurangan total jarak tempuh operator dari $907,6 \mathrm{~m}$ menjadi $573,2 \mathrm{~m}$.

\section{DAFTAR PUSTAKA}

[1]. Heragu, Sundaresh, 1997, Facilities Design, Second Edition, Boston: PWS. Publishing Company.

[2]. American Society of Quality (n.d.) LSS Tool The Spaghetti Diagram. http://www.asqlongisland.org/seminars/2011_01_20_LSS_Tool_The_Spaghetti_Diag ram.pdf (diakses pada tanggal 14 September $\overline{201} \overline{5}$ )

[3]. Sutalaksana, I.Z. 2006. Teknik Perancangan Sistem Kerja. Bandung: Institut Teknologi Bandung.

[4]. Apple.1990. Tata Letak Pabrik dan Pemindahan Bahan. Edisi Ketiga. Bandung: Institut Tekknologi Bandung.

[5]. Averill M. Law and W. David Kelton. 2000. Simulation Modeling and Analysis. New York: Mc Graw-Hill.

[6]. Sukma, Novita dkk., Analisis Pengukuran Waktu Kerja dengan Metode Pengukuran Kerja Secara Langsung pada Bagian Pengemasan PT. Japfa Comfeed Indonesia Tbk. Jurusan Teknologi Industri Pertanian-Fakultas Teknologi Pertanian-Universitas Brawijaya.

[7]. Sritomo. 2009. Tata Letak Pabrik dan Pemindahan. Surabaya: GunaWidya. 